\title{
Self-Efficacy in Introductory Physics in Students at Single- Sex and Coeducational Colleges
}

\author{
Jennifer Blue ${ }^{*}$, Mary Elizabeth Mills ${ }^{\dagger}$, and Ellen Yezierski ${ }^{\Uparrow}$ \\ ${ }^{*}$ Department of Physics, Miami University, ${ }^{\dagger}$ Department of Curriculum \& Instruction, Indiana University, \\ "Department of Chemistry \& Biochemistry, Miami University
}

\begin{abstract}
We surveyed 88 students at four colleges: one men's college, two women's colleges, and one coeducational college. The questions, modified from Reid (2007), asked about in-class participation, how fulfilled they were by their achievement in their calc-based physics class, their attitude toward their class, and their self-efficacy (Bandura 1994) in the class. While a t-test showed no difference between men and women, an ANOVA showed a significant interaction between sex and type of school. Detailed results will be presented and discussed.
\end{abstract}

Keywords: Physics education, single-sex education, women's colleges, men's colleges, attitudes, self-efficacy PACS: 01.40.Fk

\section{INTRODUCTION}

Women are still underrepresented in physics. Though data from the first decade of the $21^{\text {st }}$ century show that nearly $50 \%$ of students in high school physics classes were girls, women are still earning just over $20 \%$ of the bachelor's degrees and fewer than $20 \%$ of the PhDs in physics. [1] Previous research suggests that these differences are not caused by biological sex differences. [2]

Physics classrooms can be unfriendly in both high school and college, which can cause female students' self-impression about themselves and their ability to do physics plummet. Female students in co-educational classes can be intimidated by the male students in their classes and can be afraid to ask for help or even answer questions in class. They lack assertiveness and selfconfidence, which can make physics classes even worse for girls if they are in a classroom with their male peers. [3,4.5]

Seymour and Hewitt [6] studied the reasons that undergraduate students leave science, mathematics, and engineering majors and what can help them to stay. Among the strategies that female students, in particular, use to "survive" science majors, they listed confidence in one's abilities, assertiveness, being more open and direct, not taking criticism personally, learning to let go of being self-critical, being able to relate comfortably to men, being less intimidated by faculty and male peer groups, and being ready to tackle all the work of the major.

One reason women leave physics is lower selfefficacy. Bandura [7] defined self-efficacy as the belief someone has in her own ability to succeed. Someone's self-efficacy will determine how she thinks, how she motivates herself, how she copes with stress and anxiety, and what course of study and career path she chooses. Among the ways people can build stronger self-efficacy are successful experiences (getting good grades) and social persuasion (being encouraged by classmates and given realistic feedback by instructors).

\section{Single-Sex Education}

Single-sex education has been shown to help girls in high school physics classes. $[8,9,10]$ Women also benefit from attending women's colleges. $[11,12]$ Compared to coeducational colleges, women's colleges are more likely to be dedicated to recruiting physics and astronomy majors, have high expectations and goals for their students, build confidence, have a cooperative environment, a sense of mission, and have female role models in the faculty, upper-class majors, and/or alumnae. [13] Women from women's colleges go on to graduate school in STEM at a higher rate than women from coeducational colleges; they are more self-confident and committed to their fields. [14]

There has been less research on the effect of single-sex education on male students. In one study of middle-school science and math students, girls preferred single sex classes and boys preferred coed classes. In addition, the girls in the single-sex classroom were more likely to seek out help when they needed it and to believe, at the end of the year, that they would take more science in the future and

2012 Physics Education Research Conference 
even become scientists. There were no obvious benefits for boys in single-sex classes. [15]

One study comparing men's colleges to coeducational colleges found that faculty at men's colleges asked more questions to specific students, particularly to students who had not already participated in class. Students at the men's colleges increased their participation in class over time, while both men and women at the coeducational colleges decreased their class participation. [16]

In this study, we explore the affects of singlesex colleges on women and men. Our research question is: Does attending a single-sex college affect the goals, attitudes, and self-efficacy of students in a physics class?

\section{METHODS}

To find out whether attending a single-sex college made a difference, we surveyed students at women's colleges, a men's college, and a coeducational college. The survey chosen was the Students' Motivation, Attitude, and Self-Efficacy in Science (SMASES) survey (Reid 2007). [17] The SMASES survey has questions about student learning, performance goals, achievement goals, attitude, and self-efficacy. It was originally designed to ask students about their experiences in science classes; we modified the survey by changing the word "science" to "physics". The modified survey can be seen in Figure 1.

The field sites surveyed were chosen to be as similar as possible. They are all small, liberal-arts colleges serving 1000-2000 students, 15-20 physics majors per year, and 4-8 physics professors.

An email was sent that included a link to an online survey to all students in the introductory, calculus-based classes, as well as all physics majors and minors. The email was sent to 226 students: 48 at the first women's college, 60 at the second women's college, 55 at the men's college, and 63 at the coeducational college. We had a response rate of nearly $40 \% ; 88$ students completed useable surveys. We had 30 from the first women's college, 11 from the second women's college, 26 from the men's college, and 21 from the coeducational college ( 9 women and 12 men).

The individual responses for each person were totaled to produce a final score that was used to statistically analyze the data. By doing this, we could test the internal consistency of the survey, check to see if the distribution of scores was normal, and thus more easily compare the different groups of students.

A 2 X 2 analysis of variance (ANOVA) was conducted to evaluate the effects of two education
Scale for the first part of the survey:

5=Always, $4=$ Often, $3=$ Sometimes, $2=$ Rarely, $1=$ Never

1. I participate in my introductory calculus-based physics class.

2. When I participate in my introductory calculusbased physics class, I do it to get a good grade.

3. When I participate in my introductory calculusbased physics class, I do it to perform better than other students.

4. When I participate in my introductory calculusbased physics class, I do it so that other students think that I'm smart.

5. When I participate in my introductory calculusbased physics class, I do it so that the teacher pays attention to me.

Scale for the remainder of the survey:

$5=$ SA $4=$ Agree, $3=$ No Opinion, $2=$ Disagree, $1=\mathrm{SD}$

6. During a physics course, I feel fulfilled when I achieve a good grade on a test.

7. During a physics course, I feel fulfilled when I gain confidence with the content.

8. During a physics course, I feel fulfilled when I am able to solve a difficult problem.

9. During a physics course, I feel fulfilled when the teacher accepts my ideas.

10. During a physics course, I feel fulfilled when other students accept my ideas.

11. I look forward to my physics class.

12. Physics class is fun.

13. I feel satisfied after my physics class.

14. I find it easy to get good grades in physics.

15. I am good at physics.

16. I find physics easy.

17. I have to work hard to pass physics.

18. I perform better than most of my classmates in physics.

19. My friends ask me for help in physics.

20. I help my friends with their homework in physics.

21. I am an intelligent student.

FIGURE 1. Modified SMASES Survey.

systems (single-sex and coeducation) and sex on students' SMASES scores. To evaluate the accuracy of the $p$-value generated by the ANOVA, the three underlying assumptions were tested. First was normal distribution of the independent variable for each population. To make sure of this we performed an Anderson-Darling test and found that the distribution of the data is normal for the total sample and within each group by school. This test was used because it is a trustworthy goodness-of-fit test for small samples. [18] The second assumption is that all cells have equivalent population variances for the dependent variable. To test this we used Levene's Test of Equality of Error 
Variances. Because the significance (0.072) is larger than 0.05 , the test is not significant and the variances are not significantly different. The last assumption is that we have random samples. The sample should be sufficiently large enough for the assumption to be valid. [19]

Although Likert-type data are ordinal, the scale seemed sufficiently large enough ( 5 points) to treat the data as interval-scale. To be certain that differences between agree and strongly agree (4 and 5) were congruent with differences between neutral and agree (3 and 4), we reduced the data to a three point scale ( $1=$ disagree; $2=$ neutral; $3=$ agree $)$ and re-ran the ANOVA. The results were the same as with the 5-point scale. Moreover, the total scores on a 5-point scale were transformed to ranks and reanalyzed. The results were the same as the previous two analyses. The last method of analysis we used tested internal consistency of the scaled portion of the survey. The internal consistency of the instrument was determined by computing a Cronbach Alpha (0.85). These scores are reliable for the respondents of the survey, as this value is above the accepted reliability coefficient of 0.7 .

\section{RESULTS}

To examine the data on the whole, we added the responses from each individual, reversing the numbers on the "I have to work hard" question, and then took the average by student type. With 5 points possible for each of the 21 questions, the total possible score was 105. A higher score indicates higher goals, a better attitude, and a higher self-efficacy.

Men at the coed college had the highest score $(\mathrm{M}=76.67, \mathrm{SD}=3.27)$, followed closely by women at the single-sex colleges $(\mathrm{M}=75.53, \mathrm{SD}=$ 1.79). There was a gap of a few points before the score of the men at the single-sex college $(\mathrm{M}=$ $70.18, \mathrm{SD}=2.14$ ) and another gap before the score of the women at the coed college $(\mathrm{M}=64.89, \mathrm{SD}=$ 3.78).

Two independent-samples $t$-test were conducted; the first to compare males and females and the second to compare the two education systems. The first t-test showed there was no significant different in the scores for males $(\mathrm{M}=$ 72.13, $\mathrm{SD}=10.39)$ and females $(\mathrm{M}=73.57, \mathrm{SD}=$ 12.84); $\mathrm{t}(87)=-0.58, p=0.57$. Thus, just being male or female is not a predictor of score on this survey. The second $t$-test showed there was no significant different in the scores for single-sex education $(\mathrm{M}=73.1, \mathrm{SD}=11.07)$ and coeducation $(\mathrm{M}=71.62, \mathrm{SD}=14.17) ; t(88)=0.502, p=0.62$. This means that there is no difference in the scores when comparing all students at the single-sex institutions and all students at the coeducational institution; there is no way to predict a score based only on which type of education system a student is enrolled in. From these two tests, we can see we needed to look at the combination of education type and sex.

A $2 \times 2$ ANOVA was then completed to see if there was interaction between sex and education system. The ANOVA indicated a significant interaction between education system and sex, $F(1,85)=8.93, p=0.004$, partial $\eta^{2}=0.095$. Figure 2 shows the SMASES mean scores for each school type by gender.

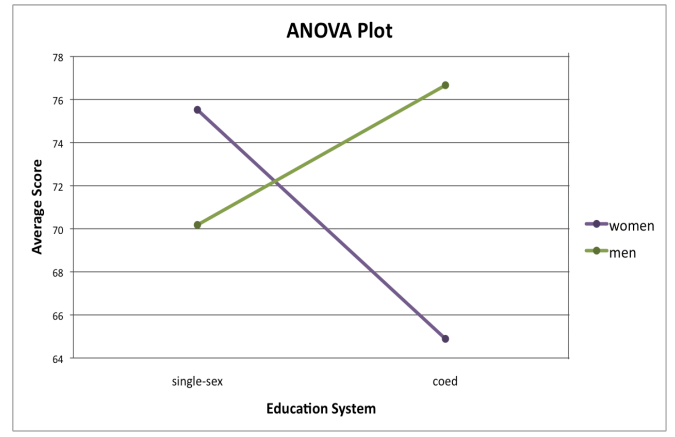

FIGURE 2. SMASES mean scores for men and women attending single-sex and coed schools.

The last method of analysis used tested internal consistency of the scaled portion of the survey. The internal consistency of the instrument was determined by computing a Cronbach Alpha (0.85). This suggests the scores are reliable for the respondents of the survey because this value is above the accepted reliability coefficient of 0.7 .

\section{DISCUSSION}

The scores of the students on the modified SMASES survey were different for students of different sexes at different types of colleges. The scores of the men at the coed college were highest, followed closely by those of the women at the women's colleges, then by those of the men at the men's college and then by the lowest scores, those of the women at the coed college. The dramatic difference between scores among the men and women at the coed college has implications for those of us who teach at coed institutions; the women and men in our classes may be quite different in their goals, attitude, and self-efficacy.

Although it appears that women, on average, have a score that is greater than their male counterparts, this difference was not statistically 
significant. It also appeared that the score for students at single-sex colleges was greater than that for students at the coed college, but that difference was not statistically significant either. That difference was also inflated by the fact that we had nearly twice as many women from women's colleges as men from the men's college in our sample, and the women at women's colleges had higher scores.

Overall, our study suggests that women still benefit from attending women's colleges, though our study does not show a similar positive effect for men. This means that either something is going on at the women's college, that is not at the coed college, to help the women feel like they can achieve or that the women who choose to go to a single-sex college are different in some way that make them more self-efficacious. This also means that there is something going on at the men's college that could be negatively affecting the men or the men who chose to go to a men's college are less self-efficacious. However, it could just as likely be that men, in general, do not succeed in a single-sex environment, as seen in previous research. Because there are only a very few men's colleges left in the USA, it would be hard to determine what is going on at these types of institutions.

There are three main limitations of this study. First, this study was only of a very small sample of students at both women's colleges and coeducational, liberal arts colleges. There are over 50 women's colleges and at least that many coeducational, liberal arts colleges that offer a physics major. Each of these colleges and universities provide a different environment for their students. Second, though we surveyed students in the courses designed for physics majors, we included the introductory course, which includes many non-majors. We did not distinguish between the responses of physics majors and nonmajors in our results. Third, people choosing not to participate in the survey made the already small sample even smaller. There were a number of students who started the survey and either did not complete it or asked for their results not to be used in the study. Also, some of the students who may have had a lower score may have self-selected out of the survey by not completing it. This may have limited the responses from students whose score would have been below our determined average. Thus our average may have been slightly inflated, but because those students chose not to respond, we do not know and cannot estimate the effect.

To make this a more comprehensive comparison, more colleges would need to be involved in the survey study and several students could be interviewed at each college. It would also be helpful to see how the students did in their classes to compare whether or not a higher selfefficacy lead to a higher achievement. In addition, it would be interesting to do a longitudinal study where students who came in to college with the intent to be a physics major could be studied to see if their major changed and how their self-efficacy evolved during college.

\section{REFERENCES}

1. American Institute of Physics, aip.org/statistics, accessed 22 June 2012.

2. J. Blue and P. Heller, "Using Matched Samples to Look for Sex Differences" in Proceedings of the 2003 PERC, 2003, Edited by K. Cummings et. al. American Institute of Physics.

3. A. Bug, Signs 28, 881-899 (2003).

4. U. Kessels and B. Hanover, British Journal of Educational Psychology 78, 273-289 (2008).

5. K. Rollin, Science \& Education 17, 1111-1115 (2008).

6. E. Seymour and N.M. Hewitt, Talking About Leaving, Boulder: Westview, 1997.

7. A. Bandura, "Self-efficacy." In Encyclopedia of Human Behavior, edited by V.S. Ramachaudran, San Diego: Academic Press, 1994, pp. 71-81.

8. E. Gillibrand, et. al. International Journal of Science Education 21, 349-362 (1999).

9. P. Robinson \& E. Gillibrand, International Journal of Science Education 26, 659-675 (2004).

10. L.G. Stowe, The Physics Teacher 26, 380-381 (1991).

11. E.A. Langdon Peabody Journal of Education 76, 530 (2001).

12. P.D. Umbach, et. al., Women Students at Coeducational and Women's Colleges, Bloomington: Indiana University Press, 2003.

13. B.L. Whitten, et. al., Journal of Women and Minorities in Science and Engineering 13, 46-51 (2007).

14. J.S. Sebrechts, Initiatives 55 45-51 (1992).

15. F.R. Spielhagen, Debating Single-Sex Education, Lanham, MD: Rowman \& Littlefield Education, 2007.

16. A.D. Trice, et. al., Education 116, $572-577$ (1996).

17. C.A. Reid, "Teacher Interpersonal Behaviour: Its Influence on Student Motivation, Self-Efficacy and Attitude Towards Science." PhD. Thesis, Curtin Institute of Technology, 2007.

18. F.W. Scholz and M.A. Stephens, Journal of the American Statistical Association 82, 918-924 (1987).

19. S.B. Green and N.J. Salkind, Using SPSS for Windows and Macintosh, Upper Saddle River, NJ: Pearson, 2010. 
Copyright of AIP Conference Proceedings is the property of American Institute of Physics and its content may not be copied or emailed to multiple sites or posted to a listserv without the copyright holder's express written permission. However, users may print, download, or email articles for individual use. 